\title{
Frequency of micronuclei in oral mucosal smears of female municipal sweepers with betel quid chewing practice
}

\author{
Archana Shetty ${ }^{1}$, Chahita Verma ${ }^{2}$, Vijaya Chowdappa ${ }^{2}$ \\ ${ }^{1}$ Department of Pathology, Sapthagiri Institute of Medical Sciences \& Research Centre, Bangalore, India \\ ${ }^{1}$ Department of Pathology Dr. Chandramma Dayananda Sagar Institute of Medical Education \& Research Centre, Banglore, India
}

\section{Keywords: \\ Betel quid; \\ Hard palate; \\ Micronuclei; \\ Oral cancer;}

\begin{abstract}
Background: Oral cancer is common worldwide. Study of micronuclei in exfoliated buccal mucosal cells holds great scope in bio monitoring their carcinogenic potential. Betel quid chewing is one of the most common factors contributing to oral cancers. Ours being a developing country, a study was undertaken among female municipal sweepers, majority of who are betel quid chewers, unaware of the harmful effects of the same. We attempted to cytologically access the presence and compare the proportion of micronuclei in the right, left buccal mucosa and hard palate of female municipal sweepers with and without betel quid chewing practice.
\end{abstract}

Materials and Methods: This was a cross sectional study with purposive sampling. Buccal smears were analysed from 30 betel quid chewers \& non chewer females for micronuclei. Mean and standard deviation were calculated. Independent $\mathrm{T}$ test was used for comparison between groups. $\mathrm{P}$ value less than 0.05 was considered statistically significant.

Results: Frequency of micronuclei in betel quid chewers and non-chewers was 26.80+/-11.96 and 7.76+/4.73. The frequency of total micronuclei per 250 cells in cases was $9.3+/-5.37$ in right buccal mucosa, $9.43+/-5.66$ in left buccal mucosa, $9.43+/-5.66$ in hard palate and 3.33+/- 2.88 in right buccal mucosa, $2.96+/-3.31$ in left buccal mucosa, and 2.96+/-3.31 in hard palate in controls.

Conclusion: The mean number of micronuclei in buccal mucosal cells of female municipal sweepers with betel quid chewing practice was significantly higher compared to controls reaffirming their carcinogenic potential and highlighting the need of early screening for oral cancer in susceptible groups.

\section{Correspondence:}

Dr. Archana Shetty, MD

Associate professor, Dr. Chandramma Dayananda Sagar Institute of Medical Education \& Research, Kanakapura Main Road, Ramanagara 562112, India

ORCID: 0000-0002-2419-1628

Email: archanashetty2924@gmail.com

Reveived : October $1^{\text {st }} 2020$; Accepted : November $2^{\text {nd }} 2020$

Citation: Shetty A, Verma C, Chowdappa VJ. Frequency of micronuclei in oral mucosal smears of female municipal sweepers with betel quid chewing practice. Pathol Nep 2021;11:1847-51. DOI: 10.3126/jpn.v11i1.31677

Copyright: This is an open-access article distributed under the terms of the Creative Commons Attribution 4.0 International License, which permits unrestricted use, distribution, and reproduction in any medium, provided the original author and source are credited.

\section{INTRODUCTION}

Oral cancer is the 6th most common cancer worldwide ${ }^{1}$ and constitutes the third most important group of malignancies in India. ${ }^{2}$ As per data available from National Cancer Registry Programme, females from our city show the highest age adjustment rate. ${ }^{3}$

It is estimated that betel quid is the fourth most addictive substance in the world after tobacco, alcohol and caffeine. ${ }^{4}$ Over 600 million people worldwide constituting about $10 \%$ of the world's population, chew betel quid. ${ }^{5}$ The International Agency for Research on Cancer (IARC) in 2004 has classified areca nut as group 1 carcinogen 6 
with elevated risks noted for oral and pharyngeal cancers. ${ }^{7}$ Though the custom of chewing betel quid has existed for thousands of years, modern studies have shown that there is a strong relationship between areca nut/ betel quid chewing and oral cancer. ${ }^{8}$ In India, it has been observed that specific occupational groups such as truck drivers, daily wage workers, and municipal sweepers are fond of betel quid chewing habits unaware of its harmful effects. ${ }^{7}$ Evaluation of the genotoxic risks in betel quid chewers on the buccal mucosa, observed as DNA damages can be assessed by exfoliated cytology such as micronuclei test. ${ }^{9}$ Micronuclei assay is a sensitive, non-invasive and low-cost technique that has been used as a biomarker for the assessment of DNA damage. ${ }^{10}$

Various studies have documented a rate of $16-37 \%$ women with betel quid chewing practice in various regions of India, the higher prevalence being in those of rural, low-income categories and with manual occupations. One such manual occupation is that of municipal sweepers, the majority of who are females. ${ }^{11}$ There is paucity in the literature about studies done exclusively in the female population of sweepers with betel quid chewing practice, hence in this, we made an attempt to cytologically assess the presence of micronuclei in exfoliated oral mucosal cells obtained from buccal smear and also to compare the frequency of micronuclei in betel quid chewers and non- chewers in three different sites of the oral cavity.

\section{MATERIALS AND METHODS}

This was a cross-sectional study with a purposive sampling method done over a period of two months. The study population was that of female municipal sweepers (also called Paurakarmikas). Study groups: Group I (Cases):30 female betel quid chewers, Group II (Controls): 30 agematched healthy females with clinically normal oral mucosa with no practice of chewing. Ethical clearance was obtained from the institutional ethical committee. IRC number:(SIMS\&RC/IECC/35/2019)

Inclusion criteria: Female municipal sweepers with the practice of chewing betel quid for equal to or more than 10 years.

Exclusion criteria: Females with a history of alcoholism/ smoking, history of previously treated precancerous/ cancerous lesion of the oral mucosa, and consumption of carcinogenic solvents.

Sample collection was done after obtaining consent from the subjects. Basic data on betel quid chewing practice and demographic details were noted. Procedure for taking smear: The subjects were asked to rinse their mouth with water. Buccal mucosal cells were scraped from the right and left buccal mucosa and hard palate ( 3 slides per case) with a wooden spatula and spread on the slides to collect the cells. The slides were fixed in 95\% ethyl alcohol. Cytological staining: PAP stain was used as it gives good nuclear chromatin details and cytoplasmic transparency. Counting the cells: Initially, the slides were focused at $40 \mathrm{X}$ magnification under a microscope to observe for adequacy. A thinly spread area with minimal overlapping of cells was chosen for counting. A minimum of 500 cells was counted in an orderly zig-zag manner. Then under 100X Magnification, micronuclei were assessed and the number of micronuclei per 250 cells was calculated.

Scoring criteria: Tolbert et $\mathrm{el}^{12}$ developed the criteria for identifying micronuclei which consist following parameters:

1. Rounded smooth perimeter suggestive of a membrane

2. Less than a third the diameter of the associated nucleus, but large enough to discern shape and color.

3. Staining intensity to the nucleus

4. Texture similar to the nucleus

5. Same focal plane as the nucleus

6. Absence of overlap with a bridge to the nucleus

Statistical analysis was done using SPSS version 20. The findings were presented as mean and standard deviation. An Independent T-test was used for comparison between groups. A P-value less than 0.05 was considered statistically significant.

\section{RESULTS}

The study was a definitive expression of micronuclei in cells cultivated from each smear. Micronuclei were single or multiple in many cells (fig. 1A and B). The micronuclei frequencies are presented in Tables 1 and 2. As per the ageadjusted group majority of the females were from the third decade of life. Also, when calculated the total average of micronuclei (right, left buccal mucosa \& hard palate together in a single study participant) in chewers was found to be $26.80+/-11.96$ and that in non-chewers was found to be $7.76+/-4.73$. As per the above table, a highly significant difference was noted between the frequency of micronuclei among chewers and non-chewers $(\mathrm{p}<0.001)$

\section{DISCUSSION}

Betel quid has an immense role in changing the oral pathology and in the biogenesis of cancer. ${ }^{13,14}$ Bloching et al. suggested micronuclei to be a cellular alteration formed due to genotoxic effects of the potential carcinogens which can be used as a prognostic biomarker of cancer. ${ }^{15}$ In a 


\begin{tabular}{|c|c|c|c|c|c|c|c|c|}
\hline \multicolumn{3}{|c|}{ Right buccal mucosa } & \multicolumn{2}{|c|}{ left buccal mucosa } & \multirow[b]{2}{*}{$\%$ controls } & \multicolumn{2}{|l|}{ Hard palate } & \multirow[b]{2}{*}{$\%$ controls } \\
\hline $\begin{array}{l}\text { Frequency Of } \\
\text { MN }\end{array}$ & $\begin{array}{l}\text { No. Of controls } \\
\text { with MN }\end{array}$ & $\%$ controls & $\begin{array}{l}\text { Frequency of } \\
\text { MN }\end{array}$ & No of controls & & $\begin{array}{l}\text { Frequency of } \\
\text { MN }\end{array}$ & No. Of controls & \\
\hline 0 & 3 & 10 & 0 & 4 & 13.33 & 0 & 9 & 30 \\
\hline 1 & 6 & 23.33 & 1 & 12 & 40 & 1 & 5 & 16.66 \\
\hline 2 & 8 & 26.66 & 2 & 3 & 10 & 2 & 5 & 16.33 \\
\hline 3 & 3 & 10 & 3 & 4 & 13.33 & 3 & 4 & 13.33 \\
\hline 4 & 1 & 3.33 & 4 & 2 & 6.66 & 4 & 1 & 3.33 \\
\hline 5 & 4 & 13.33 & 5 & 1 & 3.33 & 5 & 2 & 6.66 \\
\hline 6 & 2 & 6.66 & 6 & 1 & 3.33 & 6 & 1 & 3.33 \\
\hline 7 & 1 & 3.33 & 7 & 1 & 3.33 & 7 & 1 & 3.33 \\
\hline 8 & 0 & 0.00 & 8 & 1 & 3.33 & 8 & 1 & 3.33 \\
\hline 10 & 2 & 6.66 & 10 & 0 & 0.00 & 10 & 1 & 3.33 \\
\hline 11 & 0 & 0.00 & 11 & 1 & 3.33 & 11 & 0 & 0 \\
\hline
\end{tabular}

$M N=$ Micronucle $i$

Table 2: Frequency of micronucleated cells in cases

\begin{tabular}{|c|c|c|c|c|c|c|c|c|}
\hline \multicolumn{3}{|c|}{ Right buccal mucosa } & \multicolumn{2}{|c|}{ left buccal mucosa } & \multirow[b]{2}{*}{$\%$ cases } & \multicolumn{2}{|l|}{ Hard palate } & \multirow[b]{2}{*}{$\%$ cases } \\
\hline $\begin{array}{l}\text { Frequency Of } \\
\text { MN }\end{array}$ & $\begin{array}{l}\text { No. Of controls } \\
\text { with MN }\end{array}$ & $\%$ Cases & $\begin{array}{l}\text { Frequency of } \\
\text { MN }\end{array}$ & No of cases & & $\begin{array}{l}\text { Frequency of } \\
\text { MN }\end{array}$ & $\begin{array}{l}\text { No. Of cases } \\
\text { with MN }\end{array}$ & \\
\hline 3 & 2 & 6.66 & 3 & 1 & 3.33 & 3 & 4 & 13.33 \\
\hline 5 & 5 & 16.66 & 5 & 4 & 13.33 & 4 & 4 & 13.33 \\
\hline 6 & 1 & 3.33 & 6 & 3 & 10 & 5 & 2 & 6.66 \\
\hline 7 & 3 & 10 & 7 & 4 & 13.33 & 6 & 4 & 13.33 \\
\hline 8 & 4 & 13.33 & 8 & 4 & 13.33 & 8 & 5 & 16.66 \\
\hline 9 & 1 & 3.33 & 9 & 3 & 10 & 9 & 3 & 10 \\
\hline 10 & 3 & 10 & 10 & 3 & 10 & 10 & 4 & 13.33 \\
\hline 12 & 2 & 6.66 & 12 & 1 & 3.33 & 12 & 1 & 3.33 \\
\hline 13 & 0 & 0.00 & 13 & 1 & 3.33 & 13 & 0 & 0.00 \\
\hline 14 & 2 & 6.66 & 14 & 1 & 3.33 & 14 & 0 & 0.00 \\
\hline 15 & 3 & 10 & 15 & 1 & 3.33 & 15 & 1 & 3.33 \\
\hline 22 & 1 & 3.33 & 22 & 2 & 6.66 & 22 & 2 & 6.66 \\
\hline 25 & 1 & 3.33 & 25 & 1 & 3.33 & 25 & 0 & 0.00 \\
\hline
\end{tabular}

$M N=$ Micronucle $i$

study conducted by the international collaborative project on micronuclei, frequency in different populations and cell types, an increase in the micronuclei frequency in the target tissues and peripheral lymphocytes in cancer patients was found which further supports micronuclei to be a reliable cytogenetic biomarker. ${ }^{16}$ Therefore, in the present study, analysis of micronuclei in the epithelial cells has been used as it is a sensitive method for monitoring genetic damage in the human population. The micronuclei are the chromatincontaining bodies that represent fragments or even whole chromosomes that were not incorporated into the daughter cell nuclei at mitosis. ${ }^{17}$

In the early $1970 \mathrm{~s}$, the term 'micronucleus' was first time suggested by Boller and Schmidt and it was Heddle who showed that this is a simple point of identification to detect the genotoxic potential of mutagens after in vivo exposure of animals using the bone marrow erythrocytes. ${ }^{18}$ Theodor Boveri originally observed the fact that abnormal nuclear morphologies commonly occur in cancer. Micronuclei are also referred to as Howell-jolly bodies; discovered by haematologist William Henry Howell and Justin Marie jolly in erythrocytes. ${ }^{19}$ Oral mucosal smears are one of the time tested quick, inexpensive, and a reliable mode of obtaining a sample to study the micronuclei.

Various studies from 1985 till date have shown a significant increase in the frequency of micronuclei in betel quid chewers as compared to healthy individuals. ${ }^{19,20}$ Studies have shown a dose-response relationship, suggesting an increased relative risk of oral cancers with increasing frequency of areca nut chewing. ${ }^{21}$ A study by Gene Chen et al 


\begin{tabular}{|c|c|c|c|c|c|}
\hline & Group & Number & Mean of Micronuclel & Standard deviation & P-Value \\
\hline \multirow{2}{*}{ Right buccal mucosa } & Cases & 30 & 9.30 & 5.37 & \multirow{2}{*}{$<.00100$} \\
\hline & Controls & 30 & 3.33 & 2.88 & \\
\hline \multirow{2}{*}{ Left buccal mucosa } & Cases & 30 & 9.43 & 5.661 & \multirow{2}{*}{$<.00100$} \\
\hline & Controls & 30 & 2.96 & 3.316 & \\
\hline \multirow[t]{2}{*}{ Hard Palate } & Cases & 30 & 9.43 & 5.661 & \multirow{2}{*}{$<.00100$} \\
\hline & Controls & 30 & 2.96 & 3.316 & \\
\hline \multirow{2}{*}{ Total micronuclei } & Cases & 30 & 26.80 & 11.96 & \multirow{2}{*}{$<0.001$} \\
\hline & Controls & 30 & 7.76 & 4.73 & \\
\hline
\end{tabular}

\begin{tabular}{|c|c|c|c|c|c|}
\hline & Fareed et al ${ }^{25}$ & Agrawal et al ${ }^{2}$ & Jyoti et al ${ }^{20}$ & Sudha et al ${ }^{17}$ & Present study \\
\hline Chewers & $3.56+/-0.719$ & $44.3+/-12.1$ & $21.3+/-1.788$ & $1.90+/-1.03$ & $26.8+/-11.96$ \\
\hline Non-chewers & $0.75+/-0.171$ & $41.0+/-14.4$ & $4.56+/-0.331$ & $0.81+/-0.66$ & $7.76+/-4.73$ \\
\hline
\end{tabular}

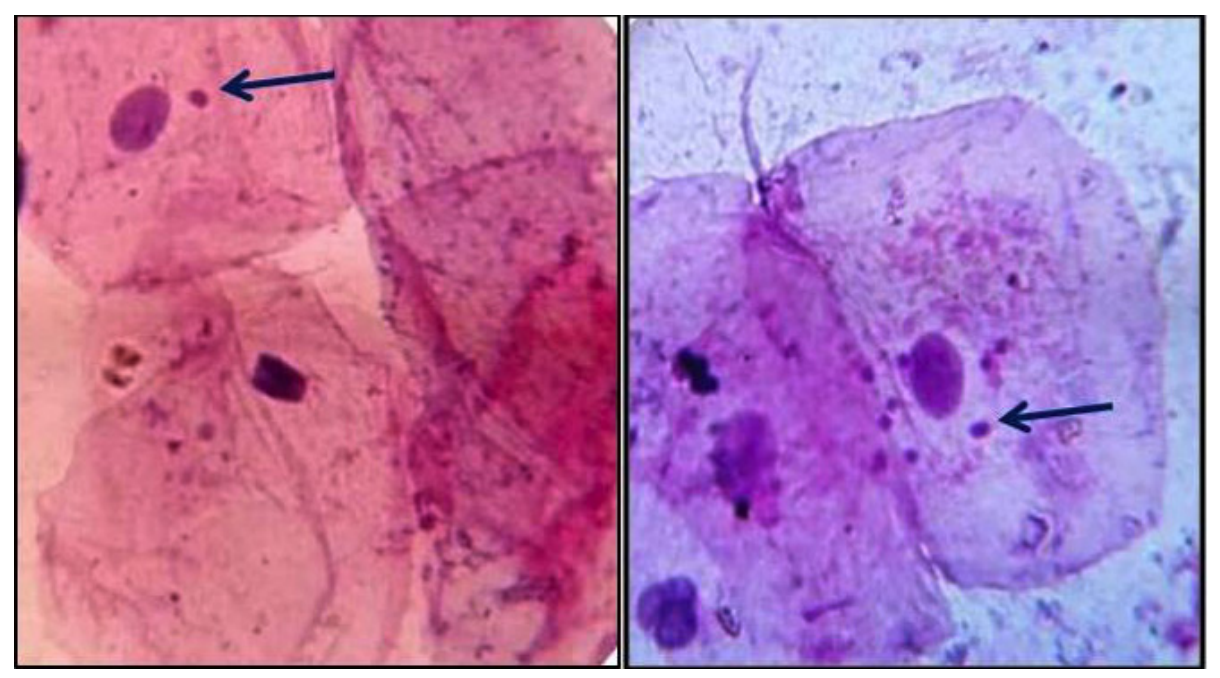

Figure 1: Buccal mucosal cells showing micronuclei (arrow) (Pap stain, X 400)

stated a hypothesis that there is a relationship between betel quid chewing and its effect on pregnancy. ${ }^{22}$ To prove this hypothesis various studies have been conducted. A research study done in Taiwan pointed out the relationship between betel quid chewing and an adverse birth outcome like low birth weight, spontaneous abortion, and preterm birth among women who chewed betel quid during gestation..$^{23,24}$

All the studies shown above demonstrate a significantly higher number of micronucleated cells in betel quid chewers as compared to healthy individuals. The present study shows a mean micronucleus of 26.8+/- 11.96 which is comparable to the findings of Khan et $\mathrm{al}^{20}$ who reported a mean value of $21.3+/-1.788$.

Sufficient and compelling evidence shows that the constituents of betel leaf, areca nut, and tobacco have cytogenic, genotoxic, and mutagenic effects on mammals.
Similar work was conducted by Kayal et al 1993 in north Indian subjects and it was reported that the chewing of areca nut alone or in combination with betel leaf and lime, caused damage to the oral mucosa. ${ }^{17}$ Higher prevalence of betel quid chewing is seen in people of rural, low-income categories and with manual occupations. One such manual occupation is that of municipal sweepers, the majority of who are females, hence this study. The assessment of this category of workers provides an opportunity to assess the relationship between occupation and oral awareness, attitude, and oral health behaviour. At the same time, it underlines the importance of implementing early screening for oral cancers in the above-mentioned susceptible groups. ${ }^{18,25}$

\section{CONCLUSIONS}

From the present study, we conclude that the frequency 
of micronuclei was found to be significantly increased in betel quid chewers as compared to non-chewers, affirming the fact that habitual female chewers like the municipal sweepers in our society might be at increased risk of developing oral cancers. The findings further highlight the need for increased awareness about the ill effects of habitual betel quid chewing practice among the susceptible population.

\section{Conflict of Interest: None}

\section{REFERENCES}

1. Shashikala R, Indira AP, Manjunath GS et al. Role of micronucleus in oral exfoliative cytology. J Pharm Bioallied Sci. 2015;7: S409-S413. Crossref

2. Agrawal V, Dubey I, Mishra KB. Evaluation of micronucleus frequency in oral exfoliated buccal mucosa cells of smokers and tobacco chewers: a comparative study. International Journal of Research in Medical Sciences.2016;4:3130-33. Crossref

3. Three Year Report of the Population Based Cancer Registries 20092011: Report of 25 PBCRs. Bangalore: National Cancer Registry Programme, Indian Council Medical Research. Website

4. Gupta PC, Warnakulasuriya S. Global epidemiology of areca nut usage. Addict Biol. 2002;7:77-83. Crossref

5. Zaw K-K, Ohnmar M, Hlaing M-M et al. Betel quid and oral potentially malignant disorders in a periurban township in Myanmar. PLoS One. 2016;11:e0162081. Crossref

6. IARC Working Group on the Evaluation of Carcinogenic Risks to Humans Betel-quid and areca-nut chewing and some areca-nut derived nitrosamines. IARC MonogrEvalCarcinog Risks Hum. 2004;85:1-334. Website

7. Trivedy CR, Craig G, Warnakulasuriya S. The oral health consequences of chewing areca nut. Addict Biol. 2002;7:115-25. Crossref

8. Lee CY, Wu CF, Chen CM et al. Qualitative study for betel quid cessation among oral cancer patients. PLoS One. 2018;13:0199503. Crossref

9. Yang $\mathrm{YH}$, Lee HY, Tung $\mathrm{S}$ et al. Epidemiological survey of oral submucous fibrosis and leukoplakia in aborigines of Taiwan. J Oral Pathol Med. 2001;30:213-9. Crossref

10. Kamath VV, AnigolP, SetlurK. Micronuclei as prognostic indicators in oral cytological smears: A comparison between smokers and nonsmokers. Clin Cancer Investig J 2014;3: 49-54. $\underline{\text { Crossref }}$

11. Holland N, Bolognesi C, Kirsch-Volders M, et al. The micronucleus assay in human buccal cells as a tool for biomonitoring DNA damage: The HUMN project perspective on current status and knowledge gaps. Mutat Res. 2008;659:93-108. Crossref

12. Tolbert PE, Shy CM, Allen JW. Micronuclei and other nuclear anomalies in buccal smears: methods development. Mutat Res. 1992;271:69-77. Crossref

13. Zain RB, Ikeda N, Gupta PC et al. Oral mucosal lesions associated with betel quid, areca nut and tobacco chewing habits: consensus from a workshop held in Kuala Lumpur, Malaysia, November 25-27, 1996. J Oral Pathol Med. 1999;28:1-4. Crossref

14. Lee $\mathrm{CH}, \mathrm{Ko} \mathrm{YC}$, Huang $\mathrm{HL}$ et al. The precancer risk of betel quid chewing, tobacco use and alcohol consumption in oral leukoplakia and oral submucous fibrosis in southern Taiwan. $\mathrm{Br} \mathrm{J}$ Cancer. 2003;88:366-72. Crossref

15. Bolognesi C, Knasmueller S, Nersesyan A et al. The HUMNxl scoring criteria for different cell types and nuclear anomalies in the buccal micronucleus cytome assay - an update and expanded photogallery. Mutat Res. 2013;753:100-13. Crossref

16. Jadhav K, Gupta N, Ahmed MB. Micronuclei: An essential biomarker in oral exfoliated cells for grading of oral squamous cell carcinoma. $\mathrm{J}$ Cytol. 2011;28:7-12. Crossref

17. Sellappa S, Balakrishnan M, Raman S et al. Induction of micronuclei in buccal mucosa on chewing a mixture of betel leaf, areca nut and tobacco. J Oral Sci. 2009;51:289-92. Crossref

18. Kashyap B, Reddy PS. Micronuclei assay of exfoliated oral buccal cells: means to assess the nuclear abnormalities in different diseases. J Cancer Res Ther. 2012;8:184-91. Crossref

19. Kausar A, Giri S, Mazumdar M et al. Micronucleus and other nuclear abnormalities among betel quid chewers with or without sadagura, a unique smokeless tobacco preparation, in a population from NorthEast India. Mutat Res. 2009;677:72-5. Crossref

20. Jyoti S, Naz F, Rahul et al. Detection of aneugenicity and clastogenicity in buccal epithelial cells of pan masala and gutkha users by pan-centromeric FISH analysis. Mutagenesis. 2015;30:2637. Crossref

21. Sinor PN, Gupta PC, Murti PR et al. A case-control study of oral submucous fibrosis with special reference to the etiologic role of areca nut. J Oral Pathol Med. 1990;19:94-8. Crossref

22. Chen G, Hsieh MY, Chen AW et al. The effectiveness of school educating program for betel quid chewing: A pilot study in Papua New Guinea. J Chin Med Assoc. 2018;81:352-57. Crossref

23. García-Algar O, Vall O, Alameda $\mathrm{F}$ et al.Prenatal exposure to arecoline (areca nut alkaloid) and birth outcomes. Arch Dis Child Fetal Neonatal Ed. 2005;90:F276-7. Crossref

24. Chue AL, Carrara VI, Paw MK et al. Is areca innocent? The effect of areca (betel) nut chewing in a population of pregnant women on the Thai-Myanmar border. Int Health. 2012;4:204-9. Crossref

25. Jyoti $\mathrm{S}$, Khan $\mathrm{S}$, Afzal $\mathrm{M}$ et al. Micronucleus investigation in human buccal epithelial cells of gutkha users. Adv Biomed Res. 2012;1:35. $\underline{\text { Crossref }}$ 